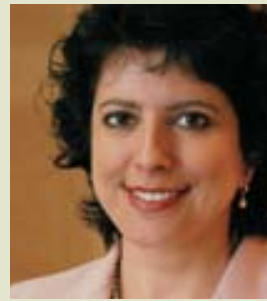

Roseli Morena Porto

FGV-EAESP roseli.porto@fgv.br

\section{Dink Family}

\section{A PARTICIPAÇÃO DAS MULHERES NO MERCADO DE TRABALHO TEM SIDO CADA VEZ MAIS EXPRESSIVA}

Evidências desse crescimento feminino apareceram na Pesquisa Nacional por Amostra de Domicílio (PNAD) de 2006, do IBGE. Por exemplo, hoje as mulheres são 43,7\% da População Economicamente Ativa (PEA) - o equivalente a 42,6 milhões.

As estatísticas, porém, não revelam os custos envolvidos nessa maior participação feminina no mercado de trabalho. Dentre eles, os associados à maternidade, mais especificamente o custo de não ter filhos. De fato, os resultados da Pesquisa Nacional do Datafolha, publicados em outubro de 2007, corroboram o aumento da preferência dos casais brasileiros em não ter filhos. Entre 1998 e 2007 cresceu de $10 \%$ para $14 \%$ o número de entrevistados que se dizem casados mas sem filhos.

Denominada de dink family (da sigla em inglês, double income, no kids), esta tendência é mais do que apenas um fato isolado, representando um novo padrão social, sobretudo entre as famílias de maior poder aquisitivo e escolaridade (nível médio a superior). Contudo, ela não é recente: em países como Estados Unidos e Japão, por exemplo, já é observada há pelo menos 20 anos. Na França, 27,6\% dos casais não têm filhos; na Alemanha, o número chega a 30\% entre as mulheres com ensino superior.

No Brasil, e segundo o Datafolha, o número de casais sem filhos aumentou, no ano 2006 (se comparado com 1998), em 15\% entre as pessoas com ensino médio e em 3\% entre as com ensino superior (onde as dink families já eram uma tendência, daí o baixo crescimento em 2006). A explicação do fenômeno leva em conta o aumento dos riscos relacionados à criação, o alto custo de manter um filho, a prevalência de um interesse maior pela carreira e a intensificação da jornada de trabalho para as mães-profissionais.

Na prática, o casal sem filhos prefere alocar seu orçamento para a compra de bens duráveis e de consumo, lazer (principalmente viagens), alimentação em restaurantes e atividades culturais.

As empresas estão se adaptando a essa nova tendência. Em várias nações européias já há estabelecimentos onde "só adultos são bem-vindos". No Brasil, observa-se o crescimento de hotéis, pousadas e condomínios concebidos exclusivamente para casais sem filhos. Outros exemplos locais incluem o boom dos pet shops de bairro e o aumento da oferta nos hipermercados de produtos e acessórios para animais de estimação.

O motivo é que muitos casais têm substituído filhos por cães e gatos. No Japão, por exemplo, há até uma fábrica de automóveis que, ao invés de oferecer carros com assentos para bebês, os têm substituído por acomodações para cachorros. O futuro acena promissoramente para iniciativas como essa. 